\title{
Pengaruh Model Pembelajaran Berbasis Masalah terhadap Kemampuan Pemecahan Masalah Fisika dan Sikap Ilmiah Siswa di SMAN 2 Kota Bengkulu
}

\author{
Silvia Anggri Wijaya, Rosane Medriati, Eko Swistoro \\ Program Studi S1 Pendidikan Fisika JPMIPA FKIP Universitas Bengkulu \\ Jl Raya Kandang Limun No 1 Bengkulu 38123 \\ E-mail : silvianggriwijaya@gmail.com
}

\begin{abstract}
ABSTRAK
Penelitian ini bertujuan untuk menguji pengaruh model pembelajaran berbasis masalah (PBM) terhadap kemampuan pemecahan masalah fisika dan peningkatan sikap ilmiah siswa. Penelitian dilakukan dengan menggunakan dua jenis disain penelitian yang berbeda, yaitu Pre-Experimental Design dengan bentuk One Group Pretest-Posttest Design untuk melihat pengaruh model PBM terhadap kemampuan pemecahan masalah dan Quasi Experimental Design dengan bentuk Nonequivalent Control Group Design untuk melihat pengaruh model PBM terhadap peningkatan sikap ilmiah. Sampel diambil menggunakan teknik purposive sampling dengan kelas X MIPA C sebagai kelas eksperimen dan kelas X MIPA D sebagai kelas kontrol. Teknik pengumpulan data menggunakan tes uraian untuk kemampuan pemecahan masalah dan angket untuk mengukur sikap ilmiah. Analisis pengaruh model PBM terhadap kemampuan pemecahan masalah dilakukan dengan perhitungan gain yaitu pengurangan rata-rata posttest dengan pretest, diperoleh hasil pengurangan sebesar 27,09, sedangkan analisis pengaruh model PBM terhadap peningkatan sikap ilmiah siswa dilakukan dengan uji-t dua sampel independen, dilihat dari skor rata-rata $N$-gain sikap ilmiah siswa kelas eksperimen dan kelas kontrol diperoleh $t_{\text {hitung }}$ lebih besar dari $t_{\text {tabel }}$ yaitu 3,47 $>2,00$ pada taraf signifikan $(\alpha=0,05)$. Maka dari hasil penelitian dapat disimpulkan terdapat pengaruh model PBM terhadap kemampuan pemecahan masalah fisika dan sikap ilmiah siswa di SMAN 2 Kota Bengkulu.
\end{abstract}

Kata kunci : Model Pembelajaran Berbasis Masalah, Kemampuan Pemecahan Masalah Fisika, dan Sikap Ilmiah.

\begin{abstract}
The aims of this study were to examine the effect of problem based learning (PBL) model to physics problem solving ability and improvement of students' scientific attitudes. This study was conducted by using two different types of research designs, namely Pre-Experimental Design with the form of One Group Pretest-Posttest Design to see the effect of PBL model to problem solving ability and Quasi Experimental Design with the form of Nonequivalent Control Group Design to see effect of PBL model on improving the students' scientific attitudes. Sampels were taken using purposive sampling technique with class X MIPA C as experiment class and class X MIPA D as control class. Data collection technique used to essay test physics problem solving ability and questionnaire to measure the students' scientific attitudes. Analysis of the effect of PBL model on the ability of physics problem solving done with the gain calculation is the average posttest reduction with pretest, then get the reduction result by 27,09 , while analysis of the effect of PBL model was to improvement of students' scientific attitudes done with two independent samples t-test, seen by average score $\mathrm{N}$-gain students' scientific attitudes in experiment class and control class get result $t_{\text {greater }}$ than $t_{\text {table }}$ is $3,47>2,00$ at significant level $(\alpha=0,05)$. Therefore, that was the result of this study concluded there is the effect of PBL model to physics problem solving ability and students' scientific attitudes at SMAN 2 Bengkulu City.
\end{abstract}

Keywords: Problem Based Learning Model, Physics Problem Solving Ability, and Scientific Attitudes.

\section{PENDAHULUAN}

Pendidikan merupakan salah satu upaya untuk mendorong kemajuan suatu bangsa. UndangUndang Nomor 20 Tahun 2003 Pasal 3 mengenai sistem pendidikan nasional menyatakan bahwa fungsi pendidikan nasional adalah mengembangkan kemampuan dan membentuk watak serta peradaban bangsa yang bermartabat dalam rangka mencerdaskan kehidupan bangsa. Berbagai upaya inovasi dalam dunia pendidikan dilakukan demi tercapainya tujuan pendidikan nasional tersebut, dimana hal yang mendasar adalah pengembangan kurikulum. Kurikulum merupakan seperangkat 
rencana pembelajaran sebagai pedoman dalam kegiatan pembelajaran untuk mencapai tujuan pendidikan tertentu ${ }^{[1]}$. Kurikulum terbaru yang digunakan dalam pembelajaran pada saat ini adalah kurikulum 2013 dengan menggunakan pendekatan saintifik. Model pembelajaran yang ditekankan pada kurikulum 2013 ini mengutamakan model pembelajaran penemuan, berbasis masalah, dan berbasis proyek ${ }^{[2]}$.

Pengembangan kurikulum 2013 ini diharapkan mampu mendorong siswa menjadi lebih aktif [3]. Salah satu model pembelajaran yang mampu mendorong siswa menjadi lebih aktif adalah model pembelajaran yang dapat memberikan siswa suatu tantangan untuk berpikir lebih dalam ketika siswa tersebut mempelajari sesuatu atau diberikan suatu masalah. Model pembelajaran yang proses pembelajarannya lebih menekankan suatu permasalahan adalah model pembelajaran berbasis masalah [4]. Adapun kelebihan model Pembelajaran Berbasis Masalah (PBM) yaitu pembelajarannya berpusat dengan masalah sehingga dapat mengembangkan kemampuan siswa dalam memecahkan masalah dan siswa berpeluang untuk meningkatkan serta mengorganisasikan pengetahuannya ${ }^{[5]}$. Model PBM dapat melatih kemampuan siswa memecahkan suatu permasalahan dalam pembelajaran fisika ${ }^{[6]}$. Pembelajaran fisika pada umumnya sangat abstrak dan terdiri atas banyak konsep dan prinsip sehingga siswa sulit dalam memahami konsep dan prinsip tersebut secara tepat. Pembelajaran fisika yang baik seharusnya tidak hanya sekedar menghapal, tetapi lebih menekankan pada proses terbentuknya suatu pengetahuan tersebut ${ }^{[4]}$.

Fisika tidak hanya sekumpulan fakta, prinsip, konsep, teori, maupun hukum-hukum tetapi juga terkandung pengembangan sikap ilmiah ${ }^{[7]}$. Sikap ilmiah adalah kecenderungan seseorang berperilaku dalam mengambil tindakan sesuai dengan metode ilmiah. Sikap ilmiah menjadi ciri kompetensi seorang ilmuwan sebagai cerminan terhadap proses dan produk sains. Sehingga sikap ilmiah sangat penting untuk diperhatikan guru dalam mempelajari sains, khususnya fisika ${ }^{[8]}$. Hasil penelitian Yustina ${ }^{[9]}$ menyebutkan bahwa terdapat perbedaan sikap ilmiah siswa antara kelas eksperimen yang menggunakan model pembelajaran berbasis masalah dengan kelas kontrol yang menggunakan metode ceramah. Kemudian penelitian yang dilakukan oleh Astika ${ }^{[10]}$ hasil penelitiannya menunjukkan bahwa model PBM berpengaruh terhadap pembentukan sikap ilmiah siswa. Sehingga, dapat disimpulkan bahwa model PBM berpengaruh terhadap kemampuan pemecahan masalah fisika dan sikap ilmiah siswa.

Berdasarkan hasil observasi dan wawancara yang dilakukan di SMAN 2 Kota Bengkulu, didapatkan bahwa pembelajaran fisika yang menerapkan kurikulum 2013 telah dilakukan di SMAN 2 Kota Bengkulu sejak tahun ajaran 2013/2014. Model pembelajaran yang digunakan guru divariasikan sesuai dengan kondisi belajar siswa. Diperoleh informasi bahwa guru fisika di SMAN 2 Kota Bengkulu telah menggunakan model PBM. Sehingga, guru juga sudah mulai mengembangkan kemampuan pemecahan masalah pada siswa. Namun, sebagian besar siswa kelas X MIPA SMAN 2 Kota Bengkulu masih kesulitan dalam menentukan langkah apa yang harus mereka lakukan untuk memecahkan permasalahan fisika yang diberikan oleh guru. Mereka hanya menghapal rumus, memasukkan angka, dan menyelesaikan persamaan matematis. Hal ini menunjukkan dalam belajar fisika siswa hanya sekedar menghapal rumus dan mendapatkan hasil, tanpa memahami konsep fisika yang ada dalam persamaan tersebut. Selain itu, siswa masih memiliki kelemahan dalam mengidentifikasi masalah berdasarkan konsep dasar fisika, menggambarkan permasalahan, dan menentukan persamaan yang tepat untuk memecahkan masalah. Disamping itu, guru sudah mulai meningkatkan dan memperhatikan sikap ilmiah siswa pada saat proses pembelajaran berlangsung khususnya ketika melakukan kegiatan praktikum, seperti sikap ingin tahu siswa yang berantusias dalam mencari jawaban dari permasalahan yang diberikan oleh guru, tidak mencontek, mengkritisi terhadap sesuatu yang keliru, menerima kritikan dari orang lain, sikap bekerja sama, dan sikap ketekunan. Akan tetapi guru belum mengukur seberapa besar sikap ilmiah siswa tersebut.

Berdasarkan latar belakang yang telah diuraikan di atas, maka dilakukan penelitian eksperimen untuk membuktikan apakah ada pengaruh model pembelajaran berbasis masalah terhadap kemampuan siswa dalam memecahkan masalah dan sikap ilmiah siswa dalam pembelajaran fisika yang didukung hasil penelitian sebelumnya. Adapun rumusan masalah dalam 
penelitian ini adalah (1) Apakah terdapat pengaruh model PBM terhadap kemampuan pemecahan masalah fisika siswa di SMAN 2 Kota Bengkulu? dan (2) Apakah terdapat pengaruh model PBM terhadap peningkatan sikap ilmiah siswa di SMAN 2 Kota Bengkulu?

\section{METODE PENELITIAN}

Jenis penelitian yang digunakan dalam penelitian ini adalah penelitian eksperimen. Sedangkan disain penelitian yang digunakan ada dua yaitu Quasi Experimental Design untuk membandingkan peningkatan sikap ilmiah siswa antara dua kelas, dan Pre-Experimental Design untuk membandingkan kemampuan pemecahan masalah fisika siswa sebelum dan setelah diajarkan dengan model PBM. Penelitian ini dilakukan dengan menggunakan dua disain karena kemampuan pemecahan masalah fisika tidak diajarkan di kelas kontrol.

Penelitian ini dilakukan pada bulan Maret-Mei 2018 di SMAN 2 Kota Bengkulu. Sampel diambil dengan teknik purposive sampling melalui pertimbangan guru fisika yang mengajar di kelas $\mathrm{X}$ MIPA. Kelas X MIPA C digunakan sebagai kelas eksperimen diajarkan menggunakan model PBM dan kelas X MIPA D digunakan sebagai kelas kontrol diajarkan menggunakan pembelajaran yang biasa digunakan oleh guru yaitu metode eksperimen.

Data dikumpulkan melalui pretest dan posttest angket sikap ilmiah siswa dan tes kemampuan pemecahan masalah fisika. Angket sikap ilmiah diberikan di kelas eksperimen dan kelas kontrol, sedangkan tes kemampuan pemecahan masalah fisika hanya diberikan di kelas eksperimen. Analisis angket sikap ilmiah dan kemampuan pemecahan masalah fisika dilakukan secara terpisah. Pengaruh model PBM terhadap peningkatan sikap ilmiah siswa dianalisis menggunakan uji t terhadap ratarata $\mathrm{N}$-gain kedua kelas. Sedangkan pengaruh model PBM terhadap kemampuan pemecahan masalah fisika diukur dengan melihat selisih posttest $\left(\mathrm{O}_{2}\right)$ dan pretest $\left(\mathrm{O}_{1}\right)$ tes kemampuan pemecahan masalah fisika $\left(O_{2}-O_{1}\right)$. Setelah dilakukan analisis didapatkan bahwa model PBM mempengaruhi sikap ilmiah siswa dan kemampuan pemecahan masalah fisika.

\subsection{Perhitungan Mean}

Untuk menghitung skor rata-rata kemampuan pemecahan masalah fisika dan sikap ilmiah siswa digunakan rumus,

$$
\bar{x}=\frac{\sum x_{i}}{n}
$$

$\bar{x}$ adalah rata-rata skor pretest atau skor posttest tes kemampuan pemecahan masalah fisika dan sikap ilmiah yang diperoleh siswa pada setiap pertemuan, $\sum x_{i}$ adalah jumlah tiap data dan $\mathrm{n}$ adalah jumlah sampel.

Adapun kriteria kemampuan pemecahan masalah adalah: 1) sangat tinggi jika $90<$ mean $\leq$ 100; 2) tinggi jika $80<$ mean $\leq 89$; 3) sedang jika $65<$ mean $\leq 79$; 4) rendah jika $55<$ mean $\leq 64$, dan 5) sangat rendah jika $0<$ mean $\leq 54^{[11]}$.

\subsection{Perhitungan Standar Deviasi}

Untuk menghitung skor standar deviasi atau simpangan baku kemampuan pemecahan masalah fisika dan sikap ilmiah siswa, digunakan persamaan:

$$
s=\sqrt{\frac{n \sum x_{i}^{2}-\left(\sum x_{i}\right)^{2}}{n(n-1)}}
$$

$\mathrm{s}$ adalah standar deviasi (simpangan baku), $\mathrm{n}$ adalah banyaknya sampel, $\sum x_{i}$ adalah jumlah semua skor $\mathrm{x}$ yang ada dalam kumparan itu, dan $\mathrm{x}_{\mathrm{i}}$ adalah skor.

\subsection{Perhitungan $N$-gain}

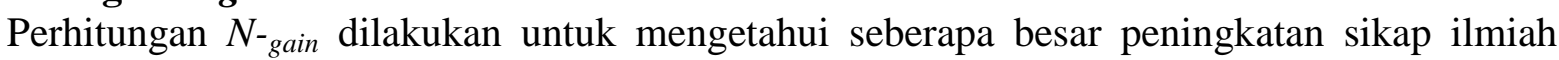
siswa yang dapat dihitung dengan menggunakan persamaan:

$$
N_{- \text {gain }}=\frac{\mathrm{S}_{\text {post }}-\mathrm{S}_{\text {pre }}}{\text { Skor maks }-\mathrm{S}_{\text {pre }}}
$$


$\mathrm{S}_{\text {pre }}$ adalah rata-rata skor pretest; $\mathrm{S}_{\text {post }}$ adalah rata-rata skor posttest; dan $\mathrm{S}_{\text {maks }}$ adalah skor maksimum. Adapun interpretasi skor $N$-gain adalah: 1) tinggi jika $\mathrm{g} \geq 0,7$; 2) sedang jika $0,3 \leq \mathrm{g}<$ 0,7 ; dan 3) rendah jika $\mathrm{g}<0,3^{[12]}$.

\subsection{Pengujian Hipotesis}

Hipotesis dalam penelitian ini ada dua yaitu $\mathrm{H}_{0}$ dan $\mathrm{H}_{a}$, dimana $\mathrm{H}_{0}$ adalah tidak terdapat pengaruh model PBM terhadap peningkatan sikap ilmiah siswa di SMAN 2 Kota Bengkulu dan $\mathrm{H}_{\mathrm{a}}$ adalah terdapat pengaruh model PBM terhadap peningkatan sikap ilmiah siswa di SMAN 2 Kota Bengkulu. Dalam penelitian ini analisis parametrik yang digunakan adalah uji t karena data rata-rata angket sikap ilmiah yang diperoleh merupakan data yang berdistribusi normal dan homogen. Karena jumlah sampel kelas kontrol dan kelas eksperimen berbeda akan tetapi homogen, maka digunakan rumus poolled varians ${ }^{[13]}$ dengan persamaan:

$$
t=\frac{\overline{x_{1}}-\overline{x_{2}}}{\sqrt{\frac{\left(n_{1}-1\right) s_{1}^{2}+\left(n_{1}-1\right) s_{2}^{2}}{n_{1}+n_{2}-2}\left(\frac{1}{n_{1}}+\frac{1}{n_{2}}\right)}}
$$

$\mathrm{t}$ adalah skor $\mathrm{t}$ hitung, $\bar{x}_{1}$ adalah skor rata-rata pretest atau posttest angket sikap ilmiah kelas eksperimen, $\bar{x}_{2}$ adalah skor rata-rata pretest atau posttest angket sikap ilmiah kelas kontrol, $n_{1}$ adalah jumlah sampel kelas eksperimen, $n_{2}$ adalah jumlah sampel kelas kontrol, $s_{1}^{2}$ adalah varian kelas eksperimen, dan $s_{2}^{2}$ adalah varian kelas kontrol. Jika harga $\mathrm{t}_{\text {hitung }} \leq \mathrm{t}_{\text {tabel }}$ pada taraf signifikansi 0,05 dan derajat kebebasan $(d k)=n_{1}+n_{2}-2$, maka $\mathrm{H}_{0}$ diterima sedangkan $\mathrm{H}_{\mathrm{a}}$ ditolak.

\section{HASIL DAN PEMBAHASAN}

\subsection{Deskripsi Data Kemampuan Pemecahan Masalah Fisika Kelas Eksperimen}

Kemampuan pemecahan masalah merupakan kemampuan yang dimiliki siswa dalam menggunakan proses berpikirnya yang diperoleh melalui belajar untuk menemukan solusi dalam memecahkan masalah. Siswa diharapkan mampu dan menjadi ahli dalam pemecah masalah, sehingga siswa dilatih untuk dapat memecahkan masalah secara sistematis. Sehingga guru sebaiknya lebih menekankan pembelajaran pemecahan masalah dan menggunakan model yang tepat untuk diterapkan dalam pembelajaran fisika. Pemecahan masalah merupakan salah satu aspek yang dipilih dalam pembelajaran menggunakan model PBM. Model PBM yang dilaksanakan di kelas eksperimen memberikan dampak kepada siswa yakni siswa berperan dalam proses pemecahan masalah.

Pada setiap pertemuan siswa diberikan soal pretest kemampuan pemecahan masalah untuk mengetahui kemampuan awal siswa sebelum pembelajaran, namun pada pertemuan pertama siswa masih belum terbiasa mengerjakan masalah fisika yang diberikan menggunakan tahapan pemecahan masalah yang sistematis. Akan tetapi, setelah siswa diajarkan menggunakan LKS berbasis masalah siswa sudah mulai terbiasa dengan pengerjaan masalah yang menggunakan tahapan pemecahan masalah fisika. Dalam penelitian ini, ada empat tahapan kemampuan pemecahan masalah menurut Sujarwanto ${ }^{[11]}$, yaitu 1) mengenali masalah, 2) merencanakan strategi, 3) menerapkan strategi, dan 4) mengevaluasi solusi.

Kemampuan pemecahan masalah fisika yang merupakan data dalam penelitian ini untuk menentukan adanya pengaruh adalah selisih antara hasil rata-rata posttest dikurang dengan rata-rata pretest, karena langkah-langkah kemampuan pemecahan masalah ini hanya diajarkan pada kelas eksperimen. Berdasarkan hasil yang diperoleh selisih antara rata-rata posttest dan rata-rata pretest sebesar 27,09. Karena terdapat selisih dari hasil pengurangan tersebut, maka dapat disimpulkan bahwa pembelajaran menggunakan model PBM memberikan pengaruh terhadap kemampuan pemecahan masalah fisika siswa. Hasil dari pengurangan ini tidak diuji normalitas dan homogenitasnya karena sampel hanya satu kelas. Grafik data hasil data rata-rata pretest dan posttest kemampuan pemecahan masalah dapat dilihat pada Gambar 1. 


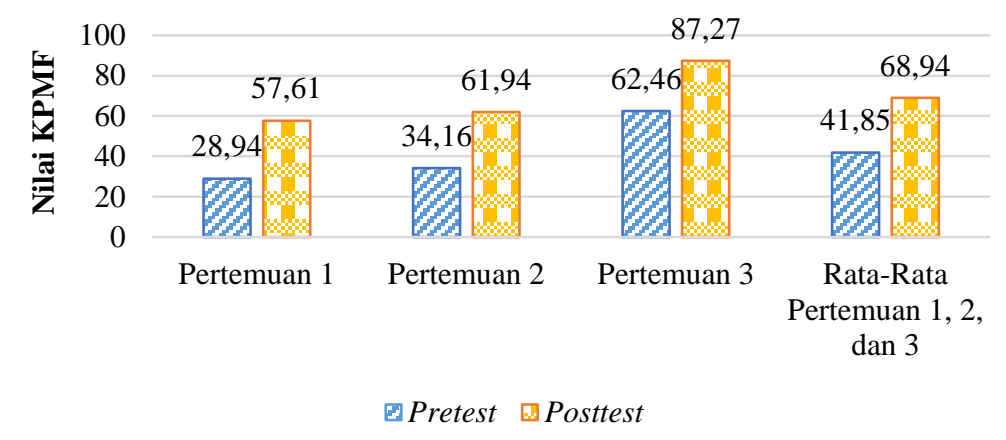

\section{Gambar 1. Grafik Hasil Data Rata-rata Pretest dan Posttest Kemampuan Pemecahan Masalah}

Berdasarkan hasil analisis mean, rata-rata kemampuan pemecahan masalah fisika siswa berada dalam kategori sedang setelah sebelumnya berada pada kategori sangat rendah. Pengaruh model pembelajaran berbasis masalah terhadap kemampuan pemecahan masalah fisika siswa dilihat dari pengurangan rata-rata posttest dengan rata-rata pretest (gain). Analisis tidak dilakukan dengan menggunakan uji perbedaan karena hanya dilakukan di satu kelas saja. Sehingga pengaruh model PBM terhadap kemampuan pemecahan masalah hanya dilihat dari ada tidaknya perubahan nilai posttest terhadap pretest.

Model PBM menuntut siswa untuk lebih aktif, kritis, dan bertanggung jawab dalam proses pembelajaran sehingga dapat melatih siswa dalam menemukan gagasan baru. Semua ini tidak terlepas dari keaktifan siswa dalam pembelajaran. Selain itu, pengaruh positif yang terjadi akibat penerapan model PBM ini adalah karena dalam pembelajaran siswa dituntut untuk menjadi pembelajar yang mandiri yang mampu memecahkan masalah sendiri dari percobaan eksperimen yang mereka lakukan. Oleh sebab itu, siswa akan lebih mudah mengerti karena terlibat langsung dalam proses pemecahan masalah. Teori ini sesuai dengan penelitian yang telah dilakukan oleh Derlina ${ }^{[14]}$ yang menyatakan bahwa dalam pembelajaran berbasis masalah, siswa dituntut untuk memecahkan masalah sendiri, sehingga pengetahuan siswa akan dibentuk melalui pengalaman langsung yang dialaminya. Selanjutnya, hasil penelitian yang dilakukan oleh Wati ${ }^{[15]}$ menunjukkan bahwa pembelajaran melalui model PBM dapat meningkatkan kemampuan pemecahan masalah siswa. Hasil penelitian Nasution ${ }^{[16]}$ juga menunjukkan bahwa terdapat pengaruh kemampuan pemecahan masalah melalui model PBM.

\subsection{Deskripsi Data Peningkatan Sikap Ilmiah Siswa Kelas Eksperimen dan Kontrol}

Sikap ilmiah yang dikembangkan dalam penelitian ini adalah sikap sebagai bagian dari proses pembelajaran Fisika. Sikap ilmiah siswa yang diukur dalam penelitian ini meliputi sikap ingin tahu, jujur, berpikir kritis, berpikiran terbuka, bekerja sama dan ketekunan. Sikap ilmiah pada dasarnya adalah sikap yang diperlihatkan oleh para ilmuwan saat mereka melakukan kegiatan sebagai seorang ilmuan atau dengan perkataan lain kecenderungan individu untuk bertindak atau berperilaku dalam memecahkan suatu masalah secara sistematis melalui langkah-langkah ilmiah ${ }^{[17]}$.

Pada penelitian ini data skor sikap ilmiah siswa diperoleh dari hasil angket. Angket sikap ilmiah siswa diberikan sebelum perlakuan (pretest) dan setelah diberi perlakuan (posttest) pada setiap pertemuan di kelas ekperimen yang mengikuti pembelajaran dengan menggunakan model PBM dan di kelas kontrol yang mengikuti pembelajaran dengan menggunakan metode eksperimen. Dari kedua kelas tersebut diukur peningkatan sikap ilmiahnya dengan memberikan angket sikap ilmiah yang telah disusun berdasarkan pedoman penyusunan kisi-kisi instrumen sikap ilmiah.

Perhitungan $\mathrm{N}$-gain dilakukan berdasarkan tes awal dan tes akhir. Gain merupakan perubahan kemampuan setelah mengikuti pembelajaran. Gain yang diperoleh dinormalisasi oleh selisih antara skor tes akhir dan skor tes awal terhadap nilai maksimum. Adapun data peningkatan sikap ilmiah siswa kelas eksperimen dan kontrol dapat dilihat pada Tabel 1.

Tabel 1. Peningkatan Sikap Ilmiah Siswa Kelas Eksperimen dan Kontrol

\begin{tabular}{lcccc}
\hline \multirow{2}{*}{ Kelas } & \multicolumn{3}{c}{ Data Sikap Ilmiah } & \multirow{2}{*}{ Kategori $N$-gain } \\
\cline { 2 - 4 } & Rata-rata pretest & Rata-rata posttest & Rata-rata N-gain & \\
\hline Eksperimen & 52,59 & 60,44 & 0,51 & Sedang \\
\hline Kontrol & 51,98 & 58,06 & 0,37 & Sedang \\
\hline
\end{tabular}


Pada Tabel 1 terlihat bahwa pencapaian skor rata-rata pretest kelas eksperimen lebih tinggi dari pencapaian skor rata-rata pretest kelas kontrol, dan pencapaian skor rata-rata posttest kelas eksperimen juga lebih tinggi dari pencapaian skor rata-rata posttest kelas kontrol. Sehingga pencapaian rata-rata $\mathrm{N}$-gain kelas eksperimen lebih tinggi dari pencapaian rata-rata $\mathrm{N}$-gain kelas kontrol, seperti yang ditunjukkan pada Gambar 2.

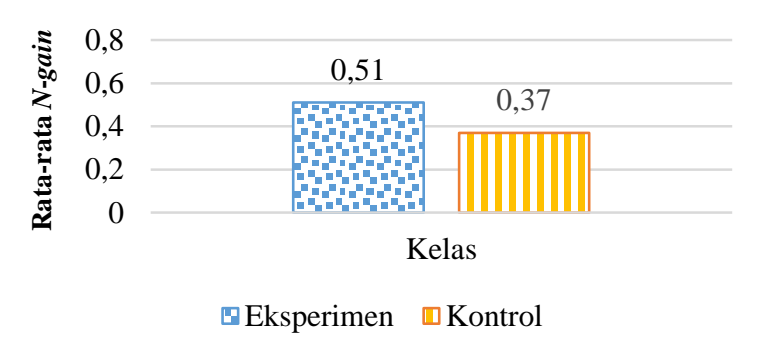

\section{Gambar 2. Grafik Data Rata-rata $N$-gain Sikap Ilmiah Siswa}

Tingginya rata-rata peningkatan sikap ilmiah siswa di kelas eksperimen ini disebabkan karena siswa di kelas ini melakukan tahapan yang terdapat dalam model pembelajaran berbasis masalah dan pembelajarannya berpusat pada siswa, sehingga dapat menimbulkan sikap ilmiah siswa. Siswa diorientasikan kepada masalah dalam kehidupan sehari-hari, kemudian siswa mengumpulkan informasi yang berhubungan dengan permasalahan yang diberikan, dan melaksanakan kegiatan praktikum untuk mendapatkan penjelasan dan pemecahan masalah. Siswa dilatih untuk memecahkan masalah secara berkelompok, dimana tiap kelompok terdiri atas 5 atau 6 orang siswa.

Pada kelas kontrol tidak melakukan tahapan yang terdapat pada pembelajaran berbasis masalah, namun di kelas kontrol siswa cenderung dengan penggunaan metode eksperimen. Siswa juga melaksanakan kegiatan praktikum, namun proses pembelajarannya masih berpusat pada guru, cenderung siswa hanya mendengarkan informasi dari guru saja, sekali-kali guru bertanya kepada siswa dan siswa diberi kesempatan untuk menjawab dan menanggapi pertanyaan dari guru serta siswa diberi kesempatan untuk bertanya.

Pada penelitian ini karena nilai $N$-gain yang diuji beda, maka hanya dilakukan uji homogenitas, karena perhitungan $\mathrm{N}$-gain data dianggap sudah ternormalisasi. Hasil perhitungan uji homogenitas varians ini menggunakan rumus perbandingan varians terbesar dibagi varians terkecil antara dua kelompok sampel dapat dilihat pada Tabel 2.

Tabel 2. Hasil Perhitungan Uji Homogenitas

\begin{tabular}{lccc}
\hline \multirow{1}{*}{ Kelas } & \multirow{2}{*}{ V } & Variabel & Varians \\
\cline { 4 - 4 } & & Sikap Ilmiah & $N$-gain \\
\hline Eksperimen & 32 & Sikap Ilmiah & 0,02 \\
\hline Kontrol & 33 & & 0,03 \\
\hline $\mathrm{F}_{\text {hitung }}$ & & & 1,18 \\
\hline $\mathrm{F}_{\text {tabel }} \alpha=0,05 \%$ & & $\mathrm{~F}_{\text {hitung }}<\mathrm{F}_{\text {tabel }}$ \\
\hline Syarat & & HOMOGEN \\
\hline Status varian & & &
\end{tabular}

Berdasarkan hasil analisis dapat disimpulkan bahwa varians kedua kelas adalah homogen. Uji homogenitas data pada kedua kelompok menunjukkan bahwa data tersebut homogen, maka statistik yang digunakan adalah statistik parametrik menggunakan uji-t dua sampel independen. Hasil analisis uji-t dua sampel independen dapat dilihat pada Tabel 3.

Tabel 3. Hasil Uji-t Sikap Ilmiah

\begin{tabular}{|c|c|c|c|c|c|c|c|}
\hline Hasil & Kelas & $\mathrm{n}$ & Rata-rata $N$-gain & Varian & $t_{\text {hitung }}$ & $\begin{array}{c}t_{\text {tabel }} \\
(\mathrm{dk}=63) \\
\alpha=0,05\end{array}$ & Kesimpulan \\
\hline \multirow{2}{*}{$\mathrm{N}$-gain } & Eksperimen & 32 & 0,51 & 0,02 & \multirow{2}{*}{3,47} & \multirow{2}{*}{2,00} & TERDAPAT \\
\hline & Kontrol & 33 & 0,37 & 0,03 & & & PERBEDAAN \\
\hline
\end{tabular}


Hasil penelitian ini menunjukkan bahwa pembelajaran berbasis masalah efektif dalam mengembangkan sikap ilmiah siswa. Penelitian yang dilakukan oleh Astika ${ }^{[10]}$ hasil penelitiannya menunjukkan bahwa terdapat perbedaan sikap ilmiah antara kelompok siswa yang belajar mengikuti model PBM dan kelompok siswa yang belajar menggunakan model pembelajaran ekspositori. Sikap ilmiah siswa yang belajar menggunakan model PBM lebih baik daripada siswa yang belajar menggunakan model pembelajaran ekspositori. Selanjutnya, menurut Sunariyati [18] hasil penelitiannya menyatakan bahwa terdapat perbedaan yang signifikan sikap ilmiah antara siswa yang belajar dengan model PBM dan siswa yang belajar dengan model pembelajaran konvensional.

\section{SIMPULAN DAN SARAN}

Berdasarkan hasil penelitian dapat disimpulkan sebagai berikut: (1) Terdapat pengaruh model PBM terhadap kemampuan pemecahan masalah fisika siswa, berdasarkan hasil analisis data diperoleh nilai gain sebesar 27,09. (2) Terdapat pengaruh model PBM terhadap peningkatan sikap ilmiah siswa, berdasarkan $t_{\text {hitung }}=3,47>t_{\text {tabel }}=2,00$ pada taraf signifikansi 0,05 .

Sebagai saran, karena penelitian ini hanya dilakukan pada satu materi saja yaitu getaran harmonik, maka diharapkan penelitian serupa dapat dilaksanakan pada materi lain, sehingga bisa mengukur sejauh mana keefektifan penggunaan model PBM terhadap kemampuan pemecahan masalah fisika dan sikap ilmiah siswa. Kemudian, diharapkan untuk penelitian selanjutnya agar dapat mengatur waktu siswa dalam mengerjakan soal pretest dan posttest kemampuan pemecahan masalah, maupun LKS agar dalam pelaksanaan pembelajaran dengan penggunaan model pembelajaran berbasis masalah dapat terlaksana dengan efektif tanpa kekurangan waktu.

\section{DAFTAR PUSTAKA}

[1] Iskandar. (2012). Psikologi Pendidikan. Jakarta: Referensi.

[2] Kemendikbud. (2014). Materi Pelatihan Implementasi Kurikulum 2013. Jakarta: Kemendikbud.

[3] Sofyan, H., \& Komariah, K. (2016). Pembelajaran Problem Based Learning dalam Implementasi 2013 di SMK. Jurnal Pendidikan Vokasi, 6(3), 260-271.

[4] Putra, A. G., Bektiarso, S., \& Handayani, R. D. (2016). Pengaruh Model Problem Based Learning (PBL) Terhadap Hasil Belajar dan Keterampilan Proses Sains dalam Pembelajaran Fisika di SMA. Jurnal Pembelajaran Fisika, 5(2), 129-134.

[5] Nurdin, H. S., \& Adriantoni. (2016). Kurikulum dan Pembelajaran. Jakarta: Raja Grafindo Persada.

[6] Maifulloh, B., Muhardjito, \& Mufti, N. (2016). Pengaruh Model Pembelajaran Problem Based Learning (PBL) terhadap Keterampilan Proses Sains Fisika Siswa Kelas X MAN 1 Malang dengan Materi Kalor. Universitas Jember, 1, hal. 78-85. Jember.

[7] Nurlaila, N., Suparmi, \& Sunarno, W. (2013). Pembelajaran Fisika dengan PBL Menggunakan Problem Solving dan Problem Posing Ditinjau dari Kreativitas dan Keterampilan Berpikir Kritis Siswa. Jurnal Inkuiri, 2(2), 114-123.

[8] Sodikin. (2015). Penerapan Pembelajaran Berbasis Masalah Melalui Metode Eksperimen dan Demonstrasi Ditinjau dari Kemampuan Menggunakan Alat Ukur dan Sikap Ilmiah Siswa. Jurnal Ilmiah Pendidikan Fisika, 4(2), 255-267.

[9] Yustina, Syafii, W., \& Apriliana, V. (2014). Peningkatan Sikap Ilmiah Siswa dalam Pembelajaran Biologi Kelas XI IPA melalui Penerapan Model Pembelajaran Problem Based Learning (PBL). Jurnal Biogenesis, 11(1), 61-66.

[10] Astika, I. K., Suma, I. K., \& Suastra, I. W. (2013). Pengaruh Model Pembelajaran Berbasis Masalah Terhadap Sikap Ilmiah dan Keterampilan Berpikir Kritis. e-Journal Program Pascasarjana Universitas Pendidikan Ganesha, 3, 1-10.

[11] Sujarwanto, E., Hidayat, A., \& Wartono, W. (2014). Kemampuan Pemecahan Masalah Fisika pada Modeling Instruction pada Siswa SMA Kelas XI. Jurnal Pendidikan IPA Indonesia, $3(1), 65-78$. 
[12] Pambudi, A., \& Wiyatmo, Y. (2017). Efektivitas Pendekatan Metakognitif dalam Pembelajaran Fisika Ditinjau dari Peningkatan Kemampuan Pemecahan Masalah Fisika Peserta Didik Kelas X SMA. Jurnal Pendidikan Fisika, 6(8), 696-703.

[13] Sugiyono. (2010). Metode Penelitian Pendidikan. Bandung: Alfabeta.

[14] Derlina, \& Pane, K. I. (2016). Kemampuan Pemecahan Masalah Siswa SMA dalam Model Pembelajaran Berbasis Masalah dengan Metode Know-Want-Learn (KWL). Jurnal Saintech, 8(3), 1-10.

[15] Wati, K. (2015). Penerapan Pendekatan Saintifik Melalui Model Problem Based Learning (PBL) Untuk Meningkatkan Kemampuan Pemecahan Masalah Belajar Siswa pada Materi Fluida Dinamik Kelas XI IPA A SMA Negeri 2 Kota Bengkulu. Skripsi pada FKIP Universitas Bengkulu: Tidak diterbitkan.

[16] Nasution, U. S., Sahyar, \& Sirait, M. (2016). Pengaruh Model Problem Based Learning dan Kemampuan Berpikir Kritis Terhadap Kemampuan Pemecahan Masalah. Jurnal Pendidikan Fisika, 5(2), 112-117.

[17] Anwar, H. (2009). Penilaian Sikap Ilmiah dalam Pembelajaran Sains. Jurnal Pelangi Ilmu, 2(5), 103-114.

[18] Sunariyati, N. L., Agung, A. A., \& Dantes, N. (2014). Pengaruh Model Pembelajaran Berbasis Masalah (Problem Based Learning/PBL) Terhadap Hasil Belajar, Keterampilan Berpikir Kritis dan Sikap Ilmiah Dalam Pembelajaran Fisika Pada Siswa Kelas XI IPA SMA Negeri 1 Kuta Tahun Pelajaran 2014/2015. e-Journal Program Pascasarjana Universitas Pendidikan Ganesha, 1-7. 